\title{
Pemfigusta Desmoglein Antikor Serum Düzeyleri ile Direkt İmmünofloresan Bulgularının Hastalığın Klinik Aktivitesi ile İlişkisi
}

\section{Relationship of Serum Levels of Anti-Desmoglein Antibodies and Direct Immunofluorescence Findings with Clinical Activity of Pemphigus}

Mediha Yılmaz, Emel Bülbül Başkan, Ferah Budak*, Hayriye Sarıcaoğlu, Şükran Tunalı

Uludağ Üniversitesi Tıp Fakültesi, Deri ve Zührevi Hastalıklar Anabilim Dalı, Bursa, Türkiye *Uludağ Üniversitesi Tıp Fakültesi, Mikrobiyoloji Anabilim Dalı, Bursa, Türkiye

\section{Özet}

Amaç: Pemfigus deri ve mukozalarda bül olușumuyla seyreden, otoimmün bir hastalıktır. Bu çalışmada bül oluşumunda rolü olan desmoglein-1 (dsg-1) ve desmoglein-3 (dsg-3)'e karşı oluşmuş antikorların saptanmasında kullanılan iki yöntem olan direkt immünfloresan (IF) inceleme ve ELISA yönteminin hastalık aktivitesi ve remisyonla ilișkisi araștırılmaktadır.

Gereç ve Yöntem: Çalışmaya 23'ü pemfigus vulgaris, 2'si pemfigus foliaseus tanısı almış toplam 25 hasta alındı. Hastaların tedavi öncesi ve klinik remisyonun 3., 6. ve 12. aylarındaki anti-dsg-1 ve anti-dsg-3 serum antikor düzeyleri ELISA ile araştırıldı. Eş zamanlı olarak aktif hastalıkta lezyon kenarından, remisyonda ise sağlam kalça derisi/alt dudak mukozasından direkt IF inceleme yapıldı. Nüks halinde tetkikler tekrarlandı.

Bulgular: Pemfigus vulgaris hastalarının tedavi öncesi 17 'sinde $(\% 73,9)$ anti-dsg-1 antikoru, hepsinde (\%100) anti-dsg-3 antikoru pozitif saptandı. İki pemfigus foliaseus olgusunda tedavi öncesi anti-dsg-1 pozitif değerlerde iken anti-dsg-3 negatif saptandı. Antidsg-1 antikor serum düzeyleri deri şiddet skoru ile ( $\mathrm{r}$ : 0,577; p: 0,003), anti-dsg-3 antikor serum düzeyleri ise oral mukoza şiddet skoru ile korele idi (r: 0,539; p: 0,008). Tam remisyona giren hastaların 16'sında (\%84,2) tedavi öncesi direkt IF'da saptanan birikim remisyonla birlikte negatiflești. Nüks gözlenen 9 hastanın hepsinde nüks sırasında anti-dsg-1 ve/veya anti-dsg-3 serum düzeylerinde artış saptandı. Dokuz olgunun 3'ünde ise klinik remisyon halinde iken nüksten 1-4 ay öncesinde serum antikor düzeylerinde yükselme tespit edildi.

Sonuç: Bu çalışmada serum desmoglein otoantikor değerlerinin hastalık şiddeti ve aktivitesi ile ilişkili olabileceğini saptadık. Klinik remisyon esnasında desmoglein antikorlarının seri ölçümleri takip ve tedavi modifikasyonunda yol gösterici olabilir. (Türkderm 2011; 45: 77-82)

Anahtar Kelimeler: Pemfigus vulgaris, pemfigus foliaseus, direkt immünfloresan, desmoglein antikorları, hastalık aktivitesi

\section{Summary}

Background and Design: Pemphigus is an autoimmune disease that results in blistering of the skin and mucous membranes. In this study, we investigated the relationship between disease activity and remission with ELISA scores and direct immunofluorescence (IF) - two methods used for the detection of antibodies against desmoglein-1 (dsg-1) and desmoglein-3 (dsg-3) that are responsible for blister formation.

Material and Method: Twenty-three pemphigus vulgaris patients and two pemphigus foliaceus patients were enrolled in the study. The serum levels of anti-dsg-1 and anti-dsg-3 antibodies were measured with ELISA before therapy and at 3, 6, and 12 month of clinical remission. Concurrently, direct IF was performed on perilesional skin during active disease and on normal buttock skin/lower lip mucosa in remission. The tests were repeated if relapse has occured.

Results: Anti-dsg-1 was detected in $17(73.9 \%)$ pemphigus vulgaris patients and anti-dsg-3 in $23(100 \%)$ pemphigus vulgaris patients. In two pemphigus foliaceus patients, anti-dsg-1 values were positive, while anti-dsg-3 values were negative. A statistically significant correlation was seen between anti-dsg-1 antibody serum levels and skin severity scores (r: 0.577; p: 0.003), as well as between anti-dsg-3 antibody serum levels and oral mucosa severity scores ( $r: 0.539 ; p: 0.008)$. Direct IF results in 16 patients (84.2\%) who achieved complete remission were negative. In 9 patients who relapsed, elevated serum values of anti-dsg-1 and/or anti-dsg3 were also found. Increase in serum antibody levels was detected 1-4 months before the relapse in three of them.

Conclusion: In this study, we observed that serum desmoglein antibody levels correlated with disease severity and activity. In clinical remission, serial measurements of desmoglein antibodies can provide a guide for clinical follow-up and treatment modification. (Turkderm 2011; 45: 77-82)

Key Words: Pemphigus vulgaris, pemphigus foliaceus, direct immunofluorescence, desmoglein antibodies, disease activity

Yazı̧ma Adresi/Address for Correspondence: Dr. Emel Bülbül Başkan, Uludağ Üniversitesi Tip Fakültesi, Dermatoloji Anabilim Dalı, 16059, Bursa, Türkiye Tel.: +90 2242950741 E-posta: emel@uludag.edu.tr Geliş Tarihi/Received: 23.08.2010 Kabul Tarihi/Accepted: 01.10.2010

Türkderm-Deri Hastalıkları ve Frengi Arşivi Dergisi, Galenos Yayınevi tarafından basılmıştır.

Turkderm-Archives of the Turkish Dermatology and Venerology, published by Galenos Publishing. 


\section{Giriş}

Pemfigus yaşamı tehdit eden, kronik seyirli, otoimmün, büllöz bir hastalıktır. Pemfigusun klasik iki formu pemfigus vulgaris (PV) ve pemfigus foliaseus (PF) tur. Her iki pemfigus formu da akantolizis denen epidermal hücrelerin birbirinden ayrılması ile karakterizedir. Akantolizis sonucu deri ve mukozalarda intraepidermal bül oluşumu gerçekleşir ${ }^{1-3}$.

Pemfigus grubu hastalıklardaki temel patoloji olan akantolizis gelişiminde, hücreler arası bağlantıyı sağlayan desmozomal bütünlüğün bozulması rol oynar. Desmozomal bütünlüğün bozulması bir adezyon molekülü olan desmogleinin ekstrasellüler kısmına karşı gelişen otoantikorlar tarafından oluşturulur. Bunların arasında desmoglein 1 (dsg 1) ve desmoglein 3 (dsg 3) en iyi tanımlanmış olanlarıdı ${ }^{4-8}$.

Pemfigus hastalarının takibinde klinik düzelmenin yanında hastalık aktivitesini izlemek için adjuvan, objektif verilere gereksinim duyulmuştur. Bu amaçla değerlendirilen direkt immünfloresan (DiF) yöntem hem tanıda hem de hastalığın immünolojik aktivitesinin saptanmasında indirekt immünfloresan (iiF) yöntemine göre daha değerli bulunmuştur ${ }^{9-11}$. DiF yanında kantitatif veri elde edilmesine olanak sağlayan ELISA yöntemi ile otoantikorların takibinin de hem hastalık şiddeti hem de hastalık aktivitesi ile ilişkili olduğu bildirilmiştir ${ }^{3,12}$.

Bu çalışmada pemfigusta anti-dsg 1 ve anti-dsg 3 antikor serum düzeyleri ile DiF incelemelerin hastalık aktivitesi ve remisyon ile ilişkisini araştırmayı amaçladık.

\section{Gereç ve Yöntem}

Çalışma grubunu Nisan 2007 ile Haziran 2008 tarihleri arasında takip edilen 12'si kadın, 13'ü erkek 25 hasta oluşturmaktaydı. Klinik ve histopatolojik incelemeler sonucunda pemfigus vulgaris ve pemfigus foliaseus tanıları alan hastalar çalışmaya alındı. Çalışma öncesinde Tıbbi Araştırmalar Etik Kurulu'ndan onay alındı (etik kurul onay no:2007-7/31) ve çalışma kriterlerine uygun olarak tedaviye alınan hastalara aydınlatılmış onam belgesi imzalatıldı.

Hastaların tedavi öncesi ve eğer nüks gelişmişse nüks esnasındaki hastalık şiddetleri Harman ve ark. ${ }^{13}$ tarafından önerilen skorlama sistemine göre deri ve oral mukoza için ayrı olmak üzere derecelendirildi.

Çalışmaya alınan hastalardan tedavi öncesinde, aynı gün lezyonlu deri kenarından doku örneği ve periferik venöz kan alındı. Prednizolon $\leq 20 \mathrm{mg} / \mathrm{gün}$ tedavisi alan ve 3 aydır yeni lezyon çıkışı olmayan hastalar tam remisyon; tedavi öncesindeki lezyonların iyileşmesi ancak kısa sürede iyileşen geçici yeni lezyonların çıkışının görülmeye devam etmesi ise kısmi remisyon olarak kabul edildi. Remisyonun 3., 6. ve 12. aylarında hastalardan periferik venöz kan örnekleri ve lezyonsuz kalça bölgesinden doku örnekleri alındı ${ }^{10}$. Oral mukozaya sınırlı hastalığı olanlardan doku örneği alt dudak mukozasından alındı. Takip esnasında nüks gelişen hastalardan aynı gün lezyonlu deri kenarından doku örneği ve periferik venöz kan örnekleri tekrarlandı.

Serum anti-dsg 1 ve 3 lgG antikor düzeyleri ELISA (Mesacup Desmoglein Test "Dsg 1 ve Dsg 3"; Medical \& Biological Labo- ratuvarları, Nagoya, Japonya) ile araştırıldı. Serum örnekleri kit prosedürüne göre 1:101 oranında dilue edildi.

Doku kesitlerinde iif ile immün birikimler (IgG, IgA, IgM, C3) araştırıldı. Değerlendirme floresan mikroskopta yapıldı. Epidermis boyunca hücreler arasında kesintisiz "balık ağı" görünümündeki elma yeşili floresans pozitif olarak değerlendirildi. İstatistiksel Analiz

İstatistiksel değerlendirme 'SPSS for Windows Version 13,0' istatistik paket programı kullanılarak yapıldı. Verinin normal dağılım gösterip göstermediği Shapiro-Wilk testi ile incelendi. Normal dağılmayan veri için iki grup karşılaştırmasında MannWhitney U testi kullanıldı. Değişkenler arasındaki ilişkiler Pearson korelasyon ve Spearman korelasyon katsayıları ile incelendi. Kategorik verinin incelenmesinde Pearson Ki-kare testi ve Fisher'in Kesin Ki-kare testi kullanıldı. Anlamlılık düzeyi $\alpha=0,05$ olarak belirlendi.

\section{Bulgular}

Çalışmaya alınan hasta grubu 12 kadın (\%48), 13 erkek (\%52) olmak üzere toplam 25 kişiden oluşuyordu. Olguların yaşları 37-87

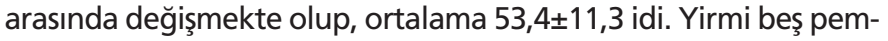
figus hastasının 23'ü (\%92) klinik ve histopatolojik olarak pemfigus vulgaris tanısı, 2'si (\%8) pemfigus foliaseus tanısı almıştı. Pemfigus vulgaris hasta grubunda 6 olguda $(\% 26,1)$ hastalık oral mukozaya sınılı iken, 17 olgu $(\% 73,9)$ mukokütanöz pemfigus vulgaris formunda idi. Hastaların 19'u (\%76) yeni tanı alan hastalar iken, 6'sı (\%24) daha önce tanı almış ancak klinik izleme devam etmeyen ve çalışmaya alınma sırasında tedavisiz dönemi takiben hastalık aktivasyonu olan hastalar idi. Olguların hastalık süreleri 1,5-19 yıl arasında değişmekte olup, ortalama 4,4 4,4 idi.

Çalışmaya alınan 25 hastanın 2'si (biri PV, biri PF) DiF için deri "punch" biyopsi örneğini vermeyi kabul etmediği için, 1 PV hastasının da tedavi öncesi alınan doku örneğinde dermoepidermal bileşke gözlenmediğinden DiF sonuçları değerlendirilmeye alınmadı. Yirmi iki hastanın 21'inde (\%95) tedavi öncesinde DiF'da balık ağı immün birikim saptandı.

Mukokütanöz pemfigus vulgarisli 17 hastanın tedavi öncesinde tamamında anti-dsg 3, 15 hastada da $(\% 88,2)$ anti-dsg 1 pozitif bulundu. Mukozal pemfigus vulgarisli 6 hastanın tedavi öncesinde hepsinde anti-dsg 3, 2 olguda da $(\% 33,3)$ anti-dsg 1 pozitif saptandı. Pemfigus foliaseuslu iki olguda tedavi öncesinde antidsg 1 pozitif, anti-dsg 3 negatifti (Tablo 1).

Hastalık şiddet derecelendirmesi deri tutulumu yönünden 7 hastada (\%28) şiddetli, 7 hastada (\%28) orta, 5 hastada (\%20) hafif şiddette idi. Oral mukoza hastalık şiddet derecelendirmesi ise 9 hastada (\%39) şiddetli, 8 hastada $(\% 34,8)$ orta, 4 hastada $(\% 17,4)$ hafif şiddette idi. Anti-dsg 1 antikor serum düzeyleri deri şiddet

Tablo 1. Tedavi öncesi pemfigus tiplerinde desmoglein antikorlarının pozitif saptanma oranları

\begin{tabular}{|c|c|c|c|}
\hline & $\begin{array}{c}\text { Mukokütanöz PV (n:17) } \\
\mathbf{n}(\%)\end{array}$ & $\begin{array}{c}\text { Mukozal PV (n:6) } \\
\mathbf{n}(\%)\end{array}$ & $\begin{array}{c}\text { PF (n:2) } \\
\mathbf{n}(\%)\end{array}$ \\
\hline Anti-dsg-1 & $15(\% 88,2)$ & $2(\% 33,3)$ & $2(\% 100)$ \\
\hline Anti-dsg-3 & $17(\% 100)$ & $6(\% 100)$ & 0 \\
\hline
\end{tabular}

PV: Pemfigus vulgaris, PF: Pemfigus foliaseus, Anti-dsg-1: Anti-desmoglein-1, Anti-dsg-3: Anti-desmoglein-3 
derecelendirmesi ile (r:0,577; p:0,003), anti-dsg-3 antikor serum düzeyleri ise oral mukoza şiddet derecelendirmesi ile anlamlı derecede ilişkili bulundu (r:0,539; p:0,008) (Şekil 1, Şekil 2).

Tüm hastaların tedavi öncesi ve remisyonun 3. ayındaki anti-dsg1 ve -3 antikor değerleri, 24 hastanın remisyonun 6 . ayındaki anti-dsg-1 ve -3 antikor değerleri, 14 hastanın remisyonun 12. ayındaki anti-dsg-1 ve -3 antikor değerleri ELISA ile ölçüldü. Bir hastada remisyonun 5. ayında iken nüks gelişmesi nedeniyle remisyonun 6 ve 12. aylarındaki anti-dsg-1 ve -3 antikor değerleri ölçülemedi. Beş hastada remisyon süresi 1 yıla tamamlanmadan nüks gözlendiğinden, 4 hastada çalışma sonlandırıldığında 12. ay remisyon süresine erişilmediğinden, 6 . ay remisyon süresini tamamlayan 1 hastada ise exitus geliştiğinden remisyonun 12. aylarındaki anti-dsg-1 ve 3 antikor değerleri ölçülemedi.

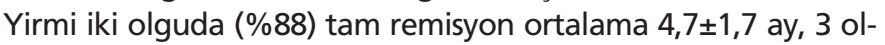
guda (\%12) kısmi remisyon ortalama $4 \pm 1$ ay sonunda gözlendi. Tam remisyona giren hastaların 16 sında $(\% 84,2)$ tedavi öncesi DiF'da saptanan immün birikim remisyonda negatifleşti.

Anti-dsg 1 değerleri tedavi öncesi pozitif saptanan 17 PV hastasının 15 'inde $(\% 88,2)$ remisyonda anti-dsg 1 değerlerinde belirgin azalma gözlendi, $13(\% 76,4)$ olguda remisyonun 3 . ayında anti-dsg 1 negatifti. Anti-dsg 1 düzeylerinde azalma gözlenmeyen 2 olgunun 1'inde takiplerinde nüks gelişirken, 1 olgu ise kısmi remisyon gözlenen hasta grubunda idi. İki pemfigus foliaseus olgusunda ise

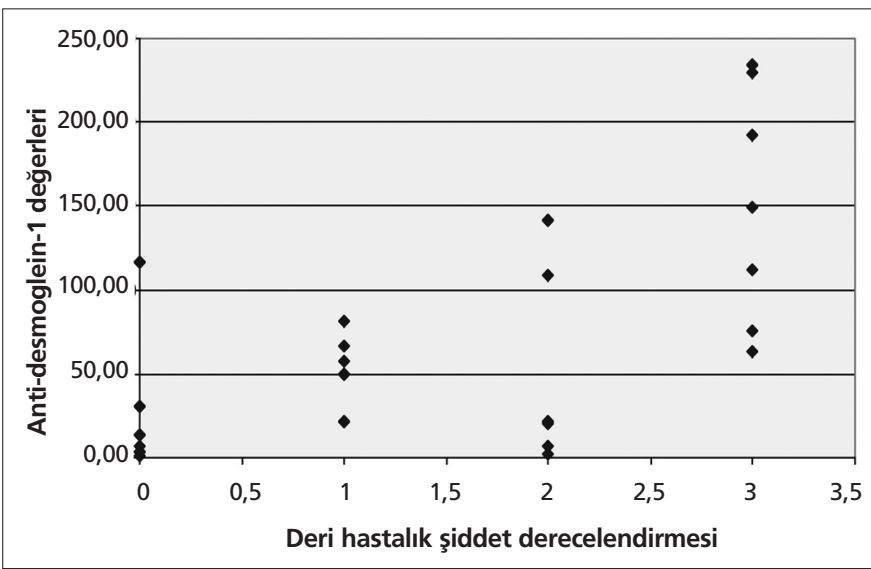

Şekil 1. Anti-dsg-1 serum antikor düzeyleri ile deri hastalık şiddet derecelendirmesi

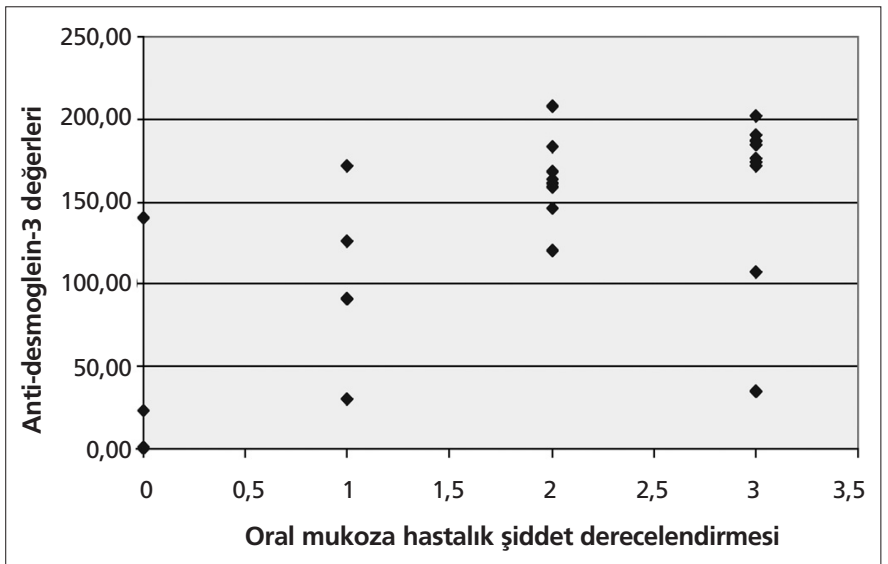

Şekil 2. Anti-dsg-3 serum antikor düzeyleri ile oral mukoza hastalık şiddet derecelendirmesi remisyonun 3. ayında anti-dsg 1 düzeylerinde belirgin azalma saptandı ancak remisyonun 6. ayında negatifleşme gözlendi. Yirmi üç pemfigus vulgaris hastasının 14 'ünde $(\% 60,8)$ remisyonda anti-dsg 3 düzeyleri belirgin azalma gösterdi, 14 olgunun $8^{\prime}$ inde $(\% 34,7)$ remisyonun 3. ayında anti-dsg 3 negatifti. Anti-dsg 3 düzeyleri azalmakla birlikte negatifleşmeyen 7 olgunun $(\% 30,4) 2$ 'sinde takiplerde nüks gelişirken 2 olgu ise kısmi remisyona girdi. Anti-dsg 3 düzeyleri yüksek seyreden $1(\% 4,3)$ olguda takipte nüks gelişti. Anti-dsg 1 ve anti-dsg 3 değerlerinde remisyona girince gözlenen azalma istatistiksel olarak anlamlı idi $(p<0,001)$. Anti-dsg 3 ortalama değerlerinin anti-dsg-1 ortalama değerlerine göre daha yüksek olduğu gözlendi. Remisyonun 12. ayında ortalama anti-dsg 3 değerlerinde saptanan yükselme, inceleme yapılan 14 olgunun 3'ünde anti-dsg 3 değerlerinde gözlenen artışa bağlandı. Desmoglein değerlerinde remisyona girince gözlenen yüzde değişimlerinde cinsiyet ve yaşa göre istatistiksel olarak anlamlı farklılık yoktu $(p>0,05)$. Mukozal ve mukokütanöz pemfigus vulgaris hastaları arasında da remisyona girince gözlenen yüzde değişimlerinde istatistiksel olarak anlamlı farklılık yoktu ( $p>0,05)$. Tedavi öncesi ve remisyon esnasındaki ortalama anti-dsg-1 ve -3 değerleri Tablo 2'de gösterilmektedir.

Tam remisyona giren 9 (\%36) pemfigus vulgaris hastasında nüks gözlendi. Nüks gözlenen hastaların 6 'sı $(\% 66,6)$ erkek, 3'ü $(\% 33,4)$ kadındı. Nüks esnasında ortalama anti-dsg 1 de-

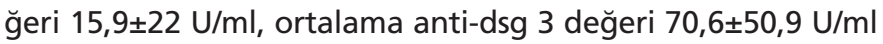
idi. Nüks gözlenen ve gözlenmeyen grup arasında hem antidsg 1 hem de anti-dsg 3 değerlerinde remisyona girince gözlenen yüzde değişimleri arasında istatistiksel olarak anlamlı farklılık yoktu $(p>0,05)$. Nüks gelişen 9 olgunun 3'ünde nüksden 1-4 ay öncesinde anti-dsg 3 serum antikor düzeylerinde yükselme saptandı. Ancak olgu sayısı yetersiz olduğundan bu yükselmenin istatistiksel anlamlığı değerlendirilemedi. İki olguda ise anti-dsg 3 değerleri klinik remisyona rağmen yüksek seyrediyordu. Nüks gözlenen ve gözlenmeyen grup arasında remisyonun ortaya çıkma süreleri açısından istatistiksel olarak anlamlı farklılık saptanmadı $(p>0,05)$.

Nüks gözlenen 9 hastanın 5 'inde $(\% 55,5)$ remisyonda negatifleşen DiF incelemede nüks sırasında immün birikim gözlendi. Ancak; anti-dsg-3 değerlerinde nüks öncesi 3 vakada gözlenen artış DiF incelemede gözlenmedi. DiF incelemelerinde remisyon ve nüks sırasında gözlenen değişiklikler Tablo 3'de gösterilmektedir.

Tablo 2. Tedavi öncesi ve remisyonun 3.,6. ve 12 aylarındaki ortalama desmoglein-1 ve -3 değerleri

\begin{tabular}{|l|c|c|c|c|}
\hline & Tedavi öncesi & $\begin{array}{c}\text { Remisyon } \\
\text { 3.ay }\end{array}$ & $\begin{array}{c}\text { Remisyon } \\
6 . \text { ay }\end{array}$ & $\begin{array}{c}\text { Remisyon } \\
\text { 12.ay }\end{array}$ \\
\hline Dsg-1(U/ml) & $73,1 \pm 71$ & $19,5 \pm 36,8$ & $11,5 \pm 24,7$ & $10,1 \pm 18,7$ \\
\hline Dsg-3(U/ml) & $144,4 \pm 54$ & $49,7 \pm 55,7$ & $46,8 \pm 54,7$ & $82,2 \pm 61$ \\
\hline Dsg-1: Desmoglein-1, Dsg-3: Desmoglein-3 \\
\hline
\end{tabular}

Tablo 3. DiF incelemelerinde remisyon ve nüks sırasında gözlenen değişiklikler

\begin{tabular}{|l|l|}
\hline & DiF \\
\hline Tedavi öncesi pozitif saptanma (\%) & 95 \\
\hline Remisyona girince negatifleşme (\%) & 84,2 \\
\hline Nüks sırasında immün birikim gözlenme (\%) & 55,5 \\
\hline
\end{tabular}




\section{Tartışma}

Pemfigusta epidermal antijenlere karşı oluşmuş otoantikorlar bül oluşumundan sorumlu tutulmaktadır-7. Klinik ve histopatolojik tanıyı bu otoantikorların çeşitli yöntemler ile saptanması desteklemektedir. Son dönemde ELISA yöntemi ile antidsg 1 ve 3 antikor seviyelerinin tespiti hassas bir tanı yöntemi olarak kullanılmaktadır ${ }^{7,14,15}$. Pemfigus vulgariste anti-dsg 3 antikorları için tanısal hassasiyet değişik çalışmalarda \%85-100 olarak bildirilmektedir ${ }^{7,14-16}$. Anti-dsg 1 antikorları ise pemfigus vulgarisli hastalarda değişik oranlarda (\%36-95 arasında) pozitif bulunmuştur ${ }^{7,15-19}$. Bu çalışmada klinik ve histopatolojik olarak pemfigus vulgaris tanısı almış olan 23 hastanın hepsinde (\% 100) anti-dsg 3 antikorları pozitif saptanırken; anti-dsg 1 pozitifliği İtalya ve İran'dan bildirilen oranlara yakın $(\% 73,9)$ bulunmuştur. Farklı çalışmalarda anti-dsg 1 otoantikorlarında değişik sıklıkta pozitiflik saptanması klinik fenotiplerde görülebilen ırksal farklılıklara bağlanmaktadır ${ }^{16,18}$. Ülkemizde Akdeniz bölgesi'nde yapılan bir çalışmada olguların \%87'sinde, İran'da ise \%69,9 oranında mukokütanöz hastalık bildirilmiştir ${ }^{16,20}$. Yüksek sıklıktaki anti-dsg 1 pozitifliği mukokütanöz fenotipin sıklığı ile ilişkili olabilir ${ }^{16}$. Bu çalışma grubunda da yakın coğrafik bölgelerde bulunan oranlara benzer şekilde \%73,9 oranda mukokütanöz hastalık saptanmıştır.

Desmoglein otoantikorlarının saptanmasında diğer bir yöntem olan DiF inceleme, çalışmalarda tedavi öncesinde \%90100 arasında değişen oranlarda pozitif bildirilmiştir ${ }^{21,22}$. Çalışmamıda benzer olarak tedavi öncesi DiF inceleme \%95 oranında pozitif saptanmıştır.

Pemfigus klinik formları desmoglein antikor profili ile ilişkilidir ${ }^{23,24}$. Çalışmamızda da klinik formlar ile antikor profili uyumlu bulunmuştur. Pemfigus foliaseus tanısı alan 2 olguda sadece anti-dsg 1 antikoru, mukozal pemfigus vulgaris tanısı olan 6 olgunun 4'ünde $(\% 66,6)$ sadece anti-dsg 3 antikoru, mukokütanöz hastalığı olan 17 vakanın 15 'inde $(\% 88,2)$ hem anti-dsg 1 hem de anti-dsg 3 antikorları pozitif bulunmuştur.

Anti-dsg 1 ve 3 otoantikorları etyopatogenezde esas rolü üstlense de yapılan araştırmalarda desmoglein dışında farklı otoantikorlar da pemfigus serumunda gösterilmiştir ${ }^{25-28}$. Anti-dsg 1 antikorlarının negatif olduğu halde 2 hastada deri lezyonlarının saptanması bu olasılığı desteklemektedir. Ayrıca desmoglein dışı antikorlardan başka desmogleinin intrasellüler kısımına karşı da antikorların geliştiği bildirilmiştir ${ }^{29}$. ELISA ile saptanamayan intrasellüler desmoglein antikorları, anti-dsg 1 negatif olduğu halde oluşan deri lezyonlarını açıklayabilir.

Hassas bir tanı yöntemi olarak kullanılan ELISA ile desmoglein antikorlarının tespitinin aynı zamanda hastalık şiddeti ile de ilişkili olduğu gösterilmiştiti3 ${ }^{3,2,13,16}$. Bu çalışmada anti-dsg-3 antikor serum düzeyleri oral mukoza şiddet derecelendirmesi ile ilişkili, deri şiddet derecelendirmesi ile ilişkisiz iken; anti-dsg-1 antikor serum düzeyleri deri şiddet derecelendirmesi ile ilişkili, oral mukoza şiddet derecelendirmesi ile ilişkisiz idi. Benzer sonuç Harman ve ark. ${ }^{13}$, Daneshpazhooh ve ark. ${ }^{16}$ ve Akman ve ark..$^{30}$ tarafından da bildirilmiştir. Çalışmamızda tam remisyon \%88, kısmi remisyon \%12 oranında gözlenmiştir. Belirtilen remisyon oranları daha önce bildirilen oranlara göre yüksektir; 1996 'da Bystryn ve Steinman ${ }^{31}$ ortalama remisyon oranını $\% 28,9,2000$ 'de Herbst ve Bystryn $\% 25$ olarak bildirmiştir. Ancak Herbst ve Bystryn ${ }^{31}$ tam remisyonu, hastanın sistemik tedavi almadığı ve 1 aydır lezyonsuz olduğu dönem olarak tanımlanmıştır, \%25'lik oran ise hastaların 6 aydır sistemik tedavi almadığı dönemde saptanmıştır. Çalışmamızda hastalarda idame tedavisi alan hastaların lezyonsuz dönemi tam remisyon olarak kabul edilmiş̧ir; saptanan yüksek remisyon oranının buna bağlı olabileceği düşünüldü. Ayrıca $\% 25$ remisyon oranı 2 . yılda saptanmış iken, 5. yılda \%50, 10. yılda \%75 oranında tam ve uzun süreli remisyon elde edildiği bildirilmiştir ${ }^{32}$. Bu konuda çalışmamızda hastaların sistemik tedavi almadığı uzun süreli takiplerinin yapılması gerektiği düşünmekteyiz.

Desmoglein antikorları hastalık şiddeti ile ilişkili olduğu gibi hastalık aktivitesiyle de paralel serum antikor düzeylerinde değişiklikler olmaktadır ${ }^{3,12,15,16,30}$. Tedavi ve remisyon sırasında desmoglein değerlerinde belirgin azalma gözlenmiştir $(15,16,33)$. Bu çalışmada da ELISA ile ölçülen hem anti-dsg 1 hem de anti-dsg 3 değerlerinde belirgin azalma saptanmıştır.

Bu çalışmada remisyonda 17 hastada $(\% 77,2)$ DiF negatif, 5 hastada $(\% 28,8)$ pozitif saptandı. Benzer çalışmalarda DiF sırasıyla remisyonda $\% 78,5 ; \% 42$ oranlarında negatif, $\% 21,5 ; \% 58$ oranlarında pozitif bildirilmiştír ${ }^{10,11}$. Gerek hastalığın aktif gerekse remisyon döneminde DiF sonuçları ile ilgili literatürdeki farklı sonuçlar farklı merkezlerde yapılan testlerin duyarlılıkları ilişkili olabilir. Klinik remisyon elde edildiği halde immün birikim saptanması patojenik antikorların nonpatojenik forma değişiminden kaynaklanabilir. Bhol ve ark. ${ }^{34}$ çalışmalarında hastalığın aktif döneminde otoantikorların IgG1 ve lgG4 alt sınıflarını, remisyon döneminde veya sağlıklı yakınlarında ise sadece IgG1 alt sınıfını içerdiğini göstermişler ve IgG1 alt sınıfının nonpatojenik veya doğal antikor olduğunu ileri sürmüşlerdir. Çalışmamızda IgG alt sınıflarına bakılamamış olması bir limitasyonudur. Remisyondaki hastalarda saptanan otoantikor ve IF pozitiflikleri ile ilgili olarak literatürde rastlanan diğer bir ilginç veri de pemfigus hastalarının sağlıklı birinci derece akrabalarında otoantikor varlığının hem serumda hem de dokuda gösterilmesidir ${ }^{35,36}$. Bu bulgu hastalığın ortaya çıkışında başka faktörlerin etkili oduğunu düşündürmektedir. Remisyonda saptanan pozitif if sonuçlarını açıklamak için diğer ihtimal ise düşük ama saptanabilen otoantikorların akantolizi indüklemediğidir ${ }^{10}$.

Bu çalışmada desmoglein değerleri yüksek seyreden 4 olgunun 3'ünde nüks geliştiği, 1 olguda ise kısmi remisyon elde edildiği saptanmıştır. Benzer sonuç desmoglein değerleri yüksek olan olgularda hastalığın da aktif saptandığı Atzori ve ark.nın ${ }^{15}$ çalışmasında da bildirilmiştir. Bunun yanında desmoglein değerleri azalmakla birlikte yüksek seyreden 6 hastanın 3'ünde remisyon elde edilmiştir. Bu durum enzim reaksiyonu esasına dayanan ELISA yönteminde yüksek titrede antikor yoğunluğu içeren serumlarda enzimin doygunluğa ulaşmasından dolayı desmoglein değerlerinin beklenenden daha düşük saptanmasına bağlı olabiliir ${ }^{37,38}$. Illeri dilüsyonlar ile aynı serumlar çalışıldığı takdirde aktif dönem ve remisyonda desmoglein değerleri arasında saptanan az farkın daha belirgin hale geleceği düşünülebilir.

Çalışmamızın önemli sonuçlarından biri nüks gelişen 9 olgunun 3'ünde nüksden 1-4 ay öncesinde ELISA ile ölçülen anti-dsg-3 serum antikor düzeylerinde yükselmenin gözlenmesidir. Ancak olgu sayımız yetersiz olduğundan bu gözlem üzerinde istatistiksel bir değerlendirme yapılamamıştır. Klinik remisyon esnasında steroid tedavisi kritik değerlere azaltılan hastalarda görülen hastalık 
nüksü tedavide güçlükler yaratmakta ve yan etki insidansını artırmaktadır. Bu yüzden remisyon esnasında serum desmoglein antikor düzeylerinde yükselme gözlenen hastalarda aynı dozda tedaviye devam edilmesini veya doz artırımına gidilmesi gerekebilir. Ancak daha önce belirtildiği gibi remisyonda da pozitif desmoglein serum düzeyleri saptanabilmektedir, bu açıdan antikorların ELISA ile seri ölçümleri ve lgG alt sınıflarının saptanması tedaviyi yönlendirmede yol gösterici olabilir.

Bu çalışmada ayrıca remisyonun 12. ayında anti-dsg 3 değerlerinde artış gözlenen 3 olgunun 1'inin serum örneklemesinden hemen önce tedaviye kısa süreli ara verdiği saptanmıştır, tedavinin devamı ile olguda klinik olarak nüks gözlenmemiştir. Anti-dsg 3 değerlerinde gözlenen artış gözlenen diğer 2 olguda örneklemeden 1 ay sonra yapılan takipte klinik remisyonun devam ettiği gözlenmiştir. Ancak doğru yorumun yapılabilmesi için bu olguların uzun süreli takipleri gerekmektedir. Çalışmamızda daha önce yapılmış çalışmalar, ${ }^{3,12,13,16,30}$ ile uyumlu olarak ELISA ile saptanan serum desmoglein otoantikor değerlerinin hastalık şiddeti ve aktivitesi ile uyumlu olduğunu gözlemledik. DiF incelemelerin de hastalık aktivitesi ile paralel seyir gösterdiğini saptadık. Ancak çalışmamızda literatürdeki araştırmalardan farklı olarak hastaların, remisyon esnasında 12 ay boyunca, daha uzun süreli takibini gerçekleştirdik. Dolayısıyla olguların uzun süreli immünolojik aktivitesi klinik bulgular ile beraber izlendi. Çalışmamızda nüks öncesi hastaların bir kısımında desmoglein otoantikoru serum düzeylerinde yükselme saptayabildik. Bu hastalarda doz azaltımının yapılmaması veya doz artırımına gidilmesi yönündeki yaklaşımın yakın vadede gündeme gelebileceğini düşünüyoruz. Sonuçlarımız hastaların takipleri esnasında desmoglein antikor serum düzeylerinin ELISA ile seri ve dilüsyonel ölçümlerinin daha anlamlı olacağını desteklemektedir. Çalışmamızda remisyon sağlandıktan en erken 4 ay sonra nüks gözlenmiştir. Dolayısıyla pemfigus hastalarında remisyon esnasında doz azaltılırken en fazla 2-3 ayda bir desmoglein serum antikor düzeylerinin takibi uygun bir yaklaşım olabilir. Sonuçlarımızın uzun süreli takipli, daha fazla sayıda olguda desmoglein ölçümlerinin yapılacağı ileri çalışmalar ile desteklenmesi gerektiğini düşünmekteyiz.

\section{Kaynaklar}

1. James W: Pemphigus: Andrew's Diseases of the Skin: Clinical Dermatology. Ed. James WD, Berger TG, Elston DM. Kanada, Saunders Elsevier, 2006;459-478.

2. Uzun S: Pemfigus. Dermatoloji. Ed. Tüzün Y, Gürer MA, Serdaroğlu S, Oğuz O, Aksungur VL. İstanbul, Nobel, 2008;807-830.

3. Bystryn JC, Rudolf JL: Pemphigus. Lancet 2005;366:61-73.

4. Stanley JR, Koulu L, Thivolet C: Distinction between epidermal antigens binding pemphigus vulgaris and pemphigus foliaceus autoantibodies. J Clin Invest 1984;73:313-20.

5. Amagai M, Hashimoto T, Gren KJ et al: Antigen-specific immunoadsorbtion of pathogenic autoantibodies in pempigus foliaceus. J Invest Dermatol 1995;104:895-901.

6. Amagai M, Klaus-Kovtun V, Stanley JR: Autoantibodies against a novel epithelial cadherin in pemphigus vulgaris, a disease of cell adhesion. Cell 1991;67:869-77.

7. Amagai $M$, Komai $A$, Hashimoto $T$ et al: Usefulness of enzyme-linked immunosorbent assay using recombinant desmogleins 1 and 3 for serodiagnosis of pemphigus. $\mathrm{Br} J$ Dermatol 1999;140:351-7.
8. Takeichi M: Cadherin cell adhesion receptors as a morphogenetic regulator. Science 1991;251:1451-5.

9. Judd KP, Lever WF: Correlation of antibodies in skin and serum with disease severity in pemphigus. Arch Dermatol 1979;115:428-32.

10. Balighi $K$, Taheri A, Mansoori P, Chams C: Value of direct immunofluorescence in predicting remission in pemphigus vulgaris. Int $J$ Dermatol 2006;45:1308-11.

11. Ratnam KV, Pang BK: Pemphigus in remission: Value of negative direct immunofluorescence in management. J Am Acad Dermatol 1994;30:547-50.

12. Hertl M: Autoimmune Disease of the skin. Wien, Springer, 2005;45-69.

13. Harman KE, Seed PT, Gratian MJ, Bhogal BS, Challacombe SJ, Black $M M$ : The severity of cutaneous and oral pemphigus is related to desmoglein 1 and 3 antibody levels. Br J Dermatol 2001;144:775-80.

14. Huang $\mathrm{CH}$, Chen $\mathrm{CC}$, Wang $\mathrm{CJ}$, Chang YT, Liu HN: Using desmoglein 1 and 3 enzyme-linked immunosorbent assay as an adjunct diagnostic tool for pemphigus. J Chin Med Assoc 2007;70:65-70.

15. Atzori L, Deidda S, Aste N: Enzyme-linked immunosorbent assay in autoimmune blistering diseases: preliminary experience of the Dermatology Department of Cagliari. G Ital Dermatol Venereol 2008; 143:1-8.

16. Daneshpazhooh M, Chams-Davatchi C, Khamesipour A et a: Desmoglein 1 and 3 enzyme-linked immunosorbent assay in Iranian patients with pemphigus vulgaris: correlation with phenotype, severity, and disease activity. J Eur Acad Dermatol Venereol 2007;21:1319-24.

17. Barnadas M, Gonzales M, Pui L et al: ELISA test in pemphigus: diagnostic value and relationship with clinical findings. J Invest Dermatol 2005; 125:1089.

18. Harman KE, Gratian MJ, Bhogal BS, Challacombe SJ, Black MM: A study of desmoglein 1 autoantibodies in pemphigus vulgaris: racial differences in frequency and the association with a more severe phenotype. Br J Dermatol 2000;143:343-8.

19. Sharma VK, Prasad HR, Khandpur S, Kumar A: Evaluation of desmoglein enzyme-linked immunosorbent assay (ELISA) in Indian patients with pemphigus vulgaris. Int J Dermatol 2006;45:518-22.

20. Uzun S, Durdu M, Akman A et al: Pemphigus in the Mediterranean region of Turkey: A study of 148 cases. Int J Dermatol 2006;45:523-8.

21. Bystryn JC: Interpretation of immunoflourencence tests in dermatology. Prog Dermatol 1985;19:1-8.

22. Sano SM, Quarracino MC, Aguas SC et al: Sensivity of direct immunoflourencence in oral diseases. Study of 125 cases. Med Oral Pathol Oral Cir Bucal 2008;13:287-91.

23. Amagai $M$, Tsunoda $K$, Zillikens $D$, Nagai $T$, Nishikawa $T$ : The clinical phenotype of pemphigus is defined by anti-desmoglein autoantibody profile. J Am Acad Dermatol 1999;40:167-70.

24. Mahoney MG, Wang Z, Rothenberger K, Koch PJ, Amagai M, Stanley JR: Explanation of the clinical and microscopic localization of lesions in pemphigus foliaceus and vulgaris. J Clin Invest 1999;103:461-8.

25. Sison-Fonacier L, Bystryn JC: Heterogeneity of pemphigus vulgaris antigens. Arch Dermatol 1987;123:1507-10.

26. Kurzen $\mathrm{H}$, Brenner S: Significance of autoimmunity non-desmoglein targets in pemphigus. Autoimmunity 2006;39:549-56.

27. Nguyen VT, Ndoye A, Shultz LD, Pittelkow MR, Grando SA: Antibodies against keratinocyte antigens other than desmogleins 1 and 3 can induce pemphigus vulgaris-like lesions. J Clin Invest 2000;106:1467-79.

28. Grando SA: Autoimmunity to keratinocyte acetylcholine receptors in pemphigus. Dermatology 2000;201:290-5.

29. Dmochowski $M$, Hashimoto $T$, Amagai $M$ et al: The extracellular aminoterminal domain of bovine desmoglein 1 (Dsg 1) is recognized only by certain pemphigus foliceus sera, whereas its intracellular domain is recognized by both by pemphigus vulgaris and pemphigus foliceus sera. J Invest Dermatol 1994;103:173-7. 
30. Akman A, Uzun S, Alpsoy E: İmmunopathologic features of pemphigus in the east mediterranean region of Turkey. A proespective study. Skinmed 2010;8:12-6.

31. Bystryn JC, Steinman NM: The adjuvant therapy of pemphigusan update. Arch Dermatol 1996;132:203-12.

32. Balighi K, Taheri A, Mansoori P, Chams C: Value of direct immunofluorescence in predicting remission in pemphigus vulgaris. Int J Dermatol 2006;45:1308-11.

33. Sami N, Bhol KC, Ahmed AR: Influence of IVIg therapy on autoantibody titers to desmoglein 1 in patients with pemphigus foliaceus. Clin Immunol 2002;105:192-8.

34. Bhol K, Mohimen A, Ahmed R: Correlation of subclasses of Ig G with disease activity in pemphigus vulgaris. Dermatology 1994;189:85-9.
35. Brandsen $\mathrm{R}$, Frusic-Zlotkin $\mathrm{M}$, Lyubimov $\mathrm{H}$ et al: Circulating pemfigus IgG in families of patients with pemphigus: Comparison of indirect immunofluorescence, direct immunofluorescence and şmmunoblotting. J Am Acad Dermatol 1997;36:44-52.

36. Günaştı S, Uzun S. Pemfiguslu hastaların sağlıklı birinci derece akrabalarında pemfigus otoantikorlarının sıklığının araştırılması. Türkiye Klinikleri J Med Sci 2010;30:571-6.

37. Kwon EJ, Yamagami J, Nishikawa T, Amagai M: Anti-desmoglein IgG autoantibodies in patients with pemphigus in remission. J Eur Acad Dermarol Venereol 2008;22:1070-5.

38. Cheng SW, Kobayashi M, Kinoshita-Kuroda K, Tanikawa A, Amagai M, Nishikawa T: Monitoring disease activity in pemphigus with enzyme-linked immunosorbent assay using recombinant desmogleins 1 and 3. Br J Dermatol 2002;147:261-5. 